\title{
Implementasi Near Field Communication (NFC) dan Kartu RFID sebagai Perangkat Mobile Presensi Mahasiswa
}

\author{
${ }^{1}$ Fajril Akbar*), ${ }^{1}$ Meza Silvana \& ${ }^{1}$ Surya Afnarius \\ 1Prodi Sistem Informasi, Fakultas Teknologi Informasi, Universitas Andalas \\ (corresponding author) ijab@ft.unand.ac.id ${ }^{\star}$ )
}

\begin{abstract}
Abstrak
Sistem presensi mahasiswa menggunakan kartu elektronik telah banyak dikembangkan dengan berbagai teknologi. Perangkat pembaca kartu elektronik yang portable menjadi salah satu solusi tentang keterbatasan tingkat ketersediaan-nya di semua ruangan kelas. Perkembangan fitur perangkat mobile yang dilengkapi dengan Near Field Communication (NFC), telah memungkinkan untuk melakukan proses transfer data secara nirkabel dengan kartu RFID tertentu[1]. Disamping itu, perangkat mobile seperti smartphone juga mampu untuk mengakses sistem informasi akademik yang telah berbasis web services. Android sebagai salah satu sistem Operasi(SO) pada smartphone, saat ini menguasai $82.8 \%$ pangsa pasar SO perangkat mobile [2]. Oleh karena itu, dalam penelitian ini dikembangka sebuah aplikasi berbasis Android dengan perangkat mobile yang terintegrasi NFC sebagai pembaca kartu RFID $13.56 \mathrm{MHz}$. Dengan melakukan analisis terhadap kebutuhan aplikasi, telah di rumuskan 4 kebutuhan fungsional aplikasi dan 4 kebutuhan nonfungsional. Analisa kebutuhan juga dirancang dalam use-case diagram, context diagram maupun data-flow level 1 diagram. Pada tahapan perancangan telah di desain antar muka, arsitektur sistem dan perancangan proses. Dalam pengimplementasian dibangun antar muka dan pemograman perangkat lunak dengan menggunakan Basic4Android. Pengujian yang dilakukan menggunakan blackbox testing terhadap 4 kebutuhan fungsional aplikasi.
\end{abstract}

Kata kunci : Sistem presensi,Android, kartu RFID, NFC

\section{Pendahuluan}

Penggunaan kartu elektronik sebagai pengganti sistem presensi manual dengan kerta, telah banyak dikembangkan. Salah satu jenis kartu elektronik adalah kartu yang menggunakan teknologi Radio Frequency Identification (RFID). Kartu ini adalah salah satu jenis proximity card, dimana tidak diperlukan kontak langsung atau mekanik dengan alat pembacanya. Permasalahan yang timbulkan selanjutnya adalah semua perangkat pembaca kartu tersebut harus dipasang di semua ruangan kelas dan terintegrasi dengan sistem informasi akademik mahasiswa. Untuk mengatasi permasalahan ini di butuhkan perangkat pembaca kartu yang portabel dan bisa terkoneksi dengan sistem informasi akademik mahasiswa yang ada.

Sebuah sistem presensi telah dirancang dengan menggunakan NFC sebagai alat bantu dosen dan mahasiswa untuk kehadiran mahasiswa dengan menggunakan perangkat Android[3]. Sistem pengecekan dilakukan dalam bentuk total presensi pada tanggal tertentu maupun siapa saja yang hadir atau tidak hadir dalam perkuliahan tersebut. Mahasiswa menggunakan perangkat NFC dapat mengirimkan informasi presensi melalui NFC dan dapat mengecek jumlah kehadiran mahasiswa tersebut. Pada penelitian ini mahasiswa dan dosen menggunakan perangkat NFC yang terintegrasi dengan smartphone.

Sementara itu, sebuah sistem smart classroom yang terintegrasi teknologi NFC teknologi untuk otomatisasi manajemen kehadiran, mencari siswa, dan menyediakan umpan balik secara realtime bagi siswa juga telah dikembangkan[4]. Teknologi NFC juga diuji sebagai tools untuk evaluasi sistem pengawasan kehadiran di Universidad Pontificia de Salamanca di Madrid, Spanyol [5]. Sistem pakar berbasiskan teknologi NFC dan telah diimplementasikan dan diuji dikampus tersebut. Di bidang kesehatan juga telah diteliti sebuah electronic data capture (EDC) sistem berbasis NFC [6]. NFC adalah cara mudah untuk diri-pelaporan informasi status kesehatan. Sistem EDC kami memungkinkan pemantauan pasien dan akuisisi data elektronik langsung dari rumah pasien.

Perangkat smartphone saat ini juga telah banyak dilengkapi dengan perangkat NFC, yang memungkinkan pengguna untuk melakukan proses transfer data melalui media nirkabel termasuk diantaranya adalah dengan kartu RFID. Disamping itu, aplikasi yang dibangun di smartphone juga memiliki kemampuan untuk mengakses sistem informasi akademik. Perangkat smartphone yang dilengkapi perangkat NFC dan aplikasi berbasis mobile merupakan solusi terbaik menjadi alat pembaca kartu RFID yang portabel.Hasil yang diharapkan dalam penelitian 
ini adalah sebuah aplikasi sistem presensi mahasiswa dengan menggunakan perangkat NFC yang berbasis Android dan kartu RFID.

\section{Metodologi}

Penelitian ini merumuskan bagaimana mengimplementasikan sebuah sistem presensi mahasiswa dengan menggunakan kartu RFID dan NFC. Dengan merancang sebuah aplikasi sistem presensi berbasiskan Android dan melakukan implementasi sistem presensi mahasiswa pada, sistem akan diuji berdasarkan kebutuhan fungsionalnya dengan metode black box.

Tahapan pembangunan perangkat lunak dilakukan dengan menggunakan metodologi SDLC (Software Development Life Cycle). Model proses pengembangan waterfall dapat dilihat pada gambar 1.

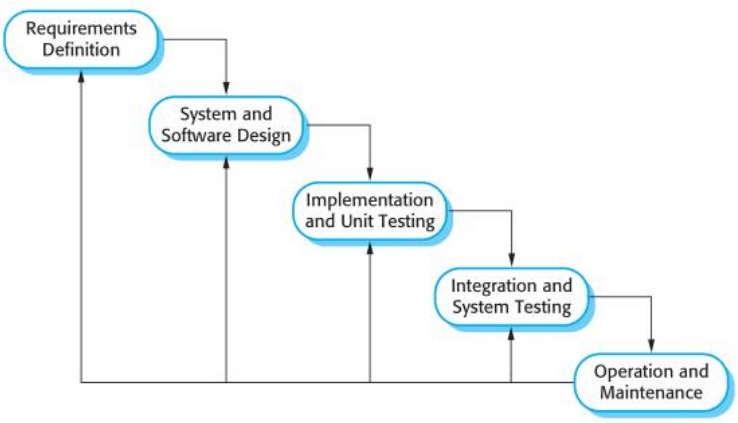

Gambar 1 model proses pengembangan perangkat lunak Waterfall

Penelitian ini mengadaptasi model proses waterfall. Tahapan-tahapan penelitian yang akan dilakukan adalah sebagai berikut:

1. Studi Literatur

Mengumpulkan literatur yang terkait dengan topik penelitian yang akan dilakukan untuk dijadikan dasar penelitian dan panduan penelitian.

2. Analisa kebutuhan

Pada tahapan ini dilakukan kajian kebutuhan yang diharapkan dari sistem presensi mahasiswa berbasiskan kartu RFID dan perangkat NFC serta batasanbatasan dari sistem yang akan dibangun. Dari tahapan ini dihasilkan daftar kebutuhan fungsional perangkat keras dan perangkat lunak yang dibangun.

3. Desain

Tahapan desain merupakan tahapan perancangan perangkat lunak yang akan dibangun. Rancangan perangkat lunak meliputi rancangan antarmuka dan rancangan proses perangkat keras yang digunakan.

4. Implementasi

Implementasi perangkat lunak dilakukan berdasarkan rancangan dari tahapan desain. Implementasi dilakukan dengan menggunakan bahasa pemrograman Android.

5. Pengujian

Menguji aplikasi yang telah dikembangkan.

\section{Analisis dan Perancangan Sistem}

Penelitian ini dilaksanakan dalam 6 tahapan. Dari semua tahapan yang direncanakan, telah diselesaikan 3 tahapan yaitu studi literatur, analisa kebutuhan dan perancangan. Pada bagian ini akan dijelaskan tahapan analisa kebutuhan dan perancangan.

\subsection{Kebutuhan Fungsional Sistem}

Analisis kebutuhan terdiri dari kebutuhan fungsional sistem, kebutuhan non-fungsional sistem, use-case diagram, context diagram dan data flow diagram dari aplikasi yang akan dibangun. Rancangan kebutuhan fungsional sistem ini disusun berdasarkan analisa terhadap fungsi aplikasi dan kajian dari aplikasi sejenis. Fungsional yang akan dibangun dalam aplikasi ini adalah:

a. User melakukan login

b. User melihat daftar matakuliah yang di ampu

c. User melihat daftar mahasiswa di matakuliah yang di ampu

d. User meng-inputkan data absensi mahasiswa dengan NFC

\subsection{Kebutuhan Non-fungsional sistem}

Adapun kebutuhan non-fungsional yang dirumuskan dalam rancangan aplikasi ini adalah:

a. Sistem memiliki proses autentifikasi pengguna aplikasi

b. Sistem memiliki tingkat ketersediaan layanan minimal 99\%

c. Besar ukuran aplikasi dibatasi sebesar maksimum 10 Mbytes.

d. Aplikasi dapat digunakan pada platform Android 
e. Response time aplikasi dipengaruhi oleh koneksi jaringan ke server.

\subsection{Use Case Diagram}

Aplikasi yang akan dibangun terdiri dari berbagai aktivitas. Aktivitas tersebut dapat di gambarkan melalui use case diagram. Diagram ini disusun berdasarkan kebutuhan fungsional sistem yang telah ditentukan sebelumnya. Use case terdiri dari 1 aktor yaitu user dan 5 use case.

\section{Tabel 1 Deskripsi Aktor}

\begin{tabular}{|l|l|l|}
\hline No. & Aktor & Deskripsi \\
\hline 1 & User & $\begin{array}{l}\text { Orang yang } \\
\text { menggunakan aplikasi } \\
\text { berdasarkan hak akses. }\end{array}$ \\
\hline
\end{tabular}

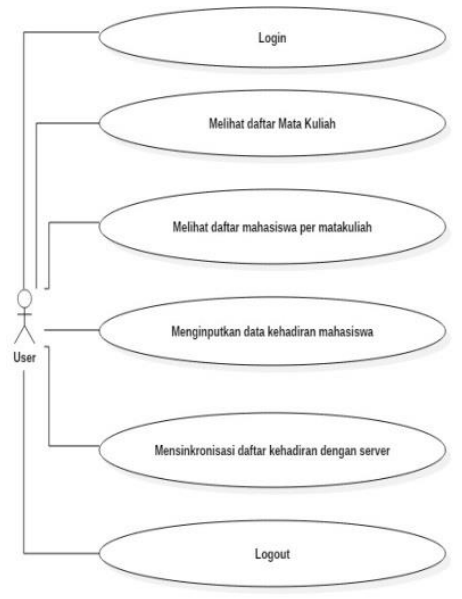

Gambar 2 use case diagram

Deskripsi actor dan use-case dapat dilihat pada Tabel 1 dan tabel 2. Use diagram aplikasi mobile ini dapat dilihat pada Gambar 2.

Tabel 2 Deskripsi use case

\begin{tabular}{|l|l|l|}
\hline No. & \multicolumn{1}{|c|}{ Usecase } & \multicolumn{1}{c|}{ Deskripsi } \\
\hline 1 & $\begin{array}{l}\text { User melakukan } \\
\text { login }\end{array}$ & $\begin{array}{l}\text { Proses login user untuk } \\
\text { mengakses data kehadiran }\end{array}$ \\
\hline 2 & $\begin{array}{l}\text { User melihat } \\
\text { daftar } \\
\text { matakuliah yang } \\
\text { diampu }\end{array}$ & $\begin{array}{l}\text { Proses melihat daftar mata } \\
\text { kuliah yang diampu oleh } \\
\text { user yang bersangkutan }\end{array}$ \\
\hline 3 & $\begin{array}{l}\text { User melihat } \\
\text { daftar } \\
\text { mahasiswa dari } \\
\text { matakuliah yang } \\
\text { diampu }\end{array}$ & $\begin{array}{l}\text { Proses memilih dan melihat } \\
\text { daftar mahasiswa per mata } \\
\text { kuliah yang diampu }\end{array}$ \\
\hline 4 & $\begin{array}{l}\text { User meng- } \\
\text { inputkan data }\end{array}$ & $\begin{array}{l}\text { Proses absensi mahasiswa } \\
\text { dengan membaca dan }\end{array}$ \\
\hline
\end{tabular}

\begin{tabular}{|l|l|l|}
\hline $\begin{array}{l}\text { absensi } \\
\text { mahasiswa } \\
\text { dengan NFC }\end{array}$ & $\begin{array}{l}\text { mencocokkan ID card yang } \\
\text { terdaftar dengan NFC }\end{array}$ \\
\hline
\end{tabular}

\subsection{Context Diagram}

Context diagram adalah diagram yanf terdiri dari suatu proses dan menggambarkan ruang lingkup suatu sistem. Context diagram merupakan level tertinggi dari Data Flow Diagram yang menggambarkan seluruh input ke sistem atau output dari sistem. Gambar 3 menunjukkan context diagram dari sistem.

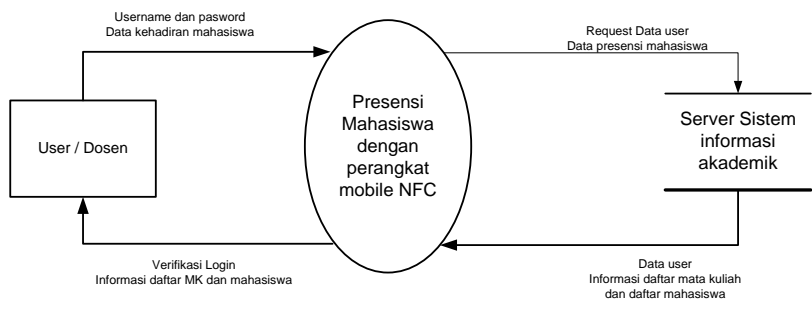

Gambar 3 context diagram

Aplikasi ini mempunyai entitas eksternal yaitu user. User akan memberikan username dan password serta data kehadiran mahasiswa kepada sistem. Sistem akan memberikan output berupa verifikasi untuk login, daftar mata kuliah dan mahasiswa sesuai dengan mata kuliah. Sistem juga akan meminta data user ke server akademik dan memberikan data presensi mahasiswa. Kemudian server akademik akan meberikan data user yang ada dan informasi mata kuliah beserta mahasiswanya kepada sistem.

\subsection{Data Flow Diagram Level 1}

Data Flow Diagram (DFD) merupakan diagram yang menggambarkan sistem sebagai suatu jaringan fungsional yang dihubungkan satu sama lain dengan alur data manual maupun komputerisasi. DFD level 1 dari aplikasi ini terdiri dari 5 data store dan 5 proses yang melibatkan user. DFD level 1 dari aplikasi yang akan dibangun dapat dilihat pada gambar 4 . 


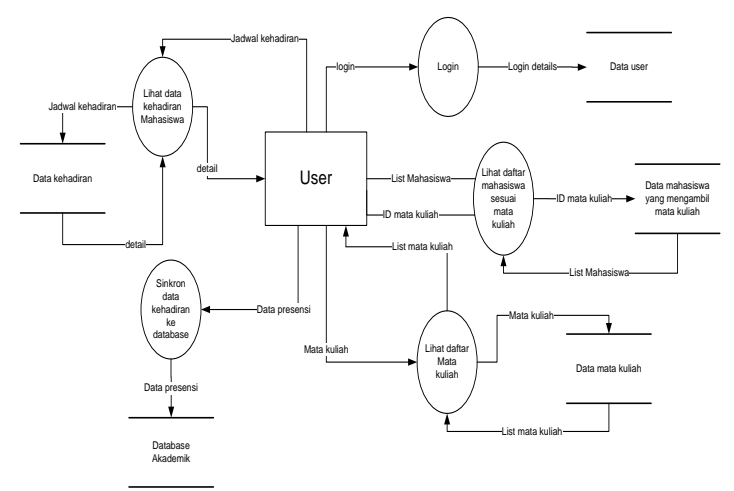

Gambar 4 data flow diagram level 1

\section{Perancangan Sistem}

Pada tahapan selanjutnya setelah melakukan analisis kebutuhan adalah perancangan sistem yang akan dibangun. Bagian ini terdiri dari perancangan arsitektur aplikasi, perancangan antar muka dan perancangan proses.

\subsection{Perancangan Arsitektur Aplikasi}

Arsitektur aplikasi ini digambarkan hubungan setiap komponen perangkat keras dan perangkat lunak yang digunakan dalam aplikasi. Web service digunakan untuk melayani request dan respon dari user dan database. Data yang dikirim ke perangkat mobile dikirim dalam format Javascript Object Notation (JSON). Sementara itu, interaksi antara web service dengan database menggunakan Structure Query Languange (SQL). Arsitektur aplikasi ini dapat dilihat pada gambar 5 .

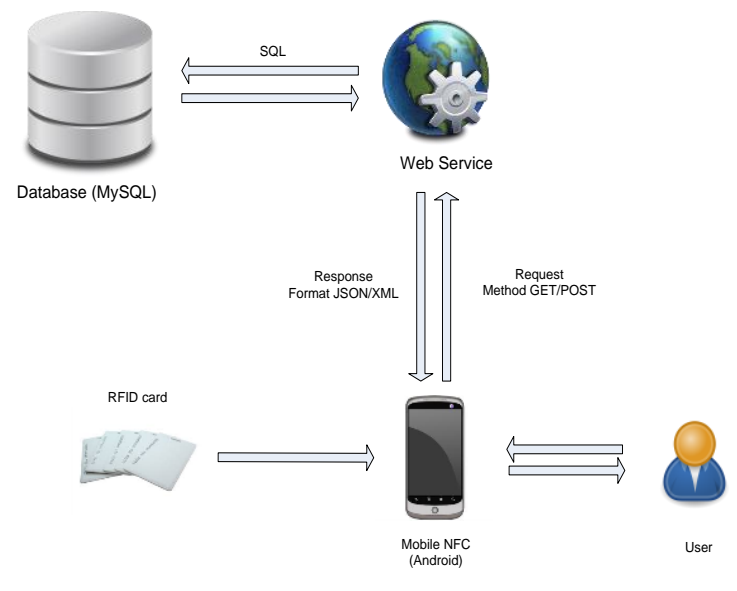

Gambar 5 arsitektur aplikasi

\subsection{Perancangan Antar Muka}

Berdasarkan kebutuhan fungsional yang telah disusun, maka telah dirancang antar muka dari aplikasi yang dibangun. Tampilan dari aplikasi ini terdiri dari beberapa komponen seperti menu, label, tombol dan komponen lainnya. Beberapa rancangan antar muka aplikasi akan disajikan dalam bagian ini.

a. Login

Halaman login terdiri dari dua bagian yaitu nama halaman dan form login. Form login terdiri dari sebuah tombol login dan 2 buah field input, yaitu username dan password untuk mengisikan akun login dari user. Rancangan halaman ini dapat dilihat pada gambar 6

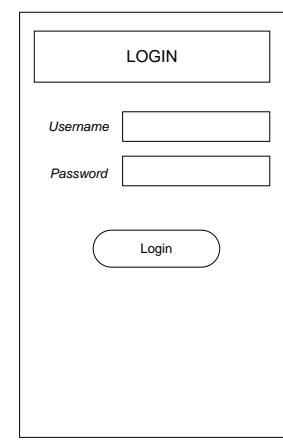

Gambar 6 rancangan halaman Login

b. Daftar Mata Kuliah yang Diampu

Halaman daftar mata kuliah terdiri dari bagian nama halaman dan daftar mata kuliah yang akan bisa di pilih user nantinya. Gambar 7 menunjukkan rancangan halaman daftar mata kuliah yang diampu.

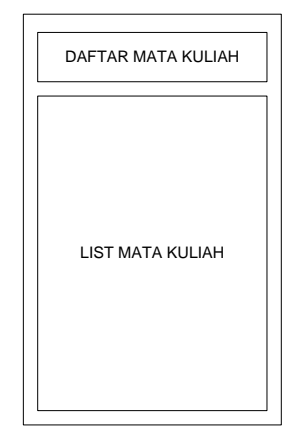

\section{Gambar 7 rancangan halaman daftar mata kuliah}

c. Daftar Mahasiswa Mata Kuliah

Halaman daftar mahasiswa mata kuliah memiliki struktur yang sama dengan halaman mata kuliah. Nama halaman diletakkan dibagian atas dan dibawahnya adalah form content yang berisi daftar mahasiswa yang akan dipilih oleh user.

d. Presensi

Halaman presensi terdiri dari bagian nama mahasiswa, nama mata kuliah, status presensi dan tombol touch. Tombol 
touch digunakan untuk men-scan ID card mahasiswa via NFC. Gambar 8 menunjukkan rancangan halaman daftar mata kuliah yang diampu.

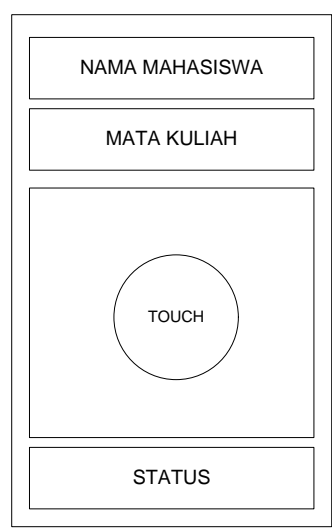

Gambar 8 rancangan halaman presensi

\subsection{Perancangan Proses}

Perancangan proses dari aplikasi ini berbentuk skenario. Skenario berfungsi untuk menampilkan urutan aktivitas aksi-reaksi antara user dengan system. Perancangan proses ini terdiri dari semua use case yang terdapat pada use-case diagram pada gambar 2 .

\section{Skenario Login}

Skenario ini merupakan kegiatan yang dilakukan oleh user untuk login ke dalam aplikasi. Skenario dapat dilihat pada tabel 3.

Tabel 3 Skenario Use Case Login

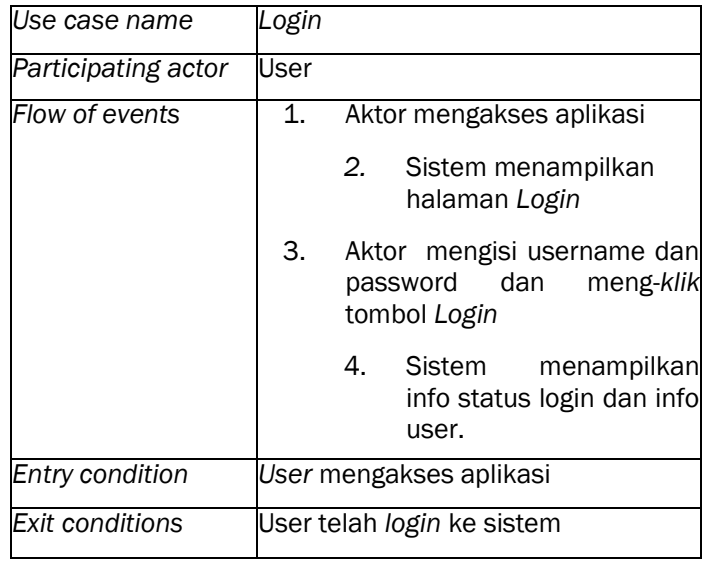

2. Skenario Use Case melihat daftar mata kuliah

Skenario Use Case melihat daftar mata kuliah ini merupakan kegiatan yang dilakukan oleh user yang valid untuk menampilkan daftar mata kuliah yang user ampu. Skenarionya dapat dilihat pada tabel 4 .

Tabel 4 Skenario Use Case melihat daftar mata kuliah

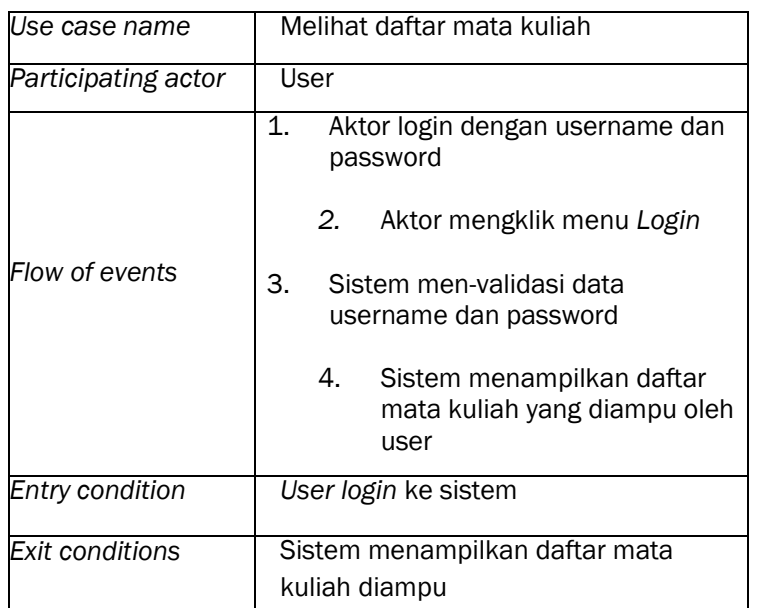

3. Skenario use case melihat daftar mahasiswa

Skenario Use Case melihat daftar mahasiswa ini merupakan kegiatan yang dilakukan oleh user untuk melihat daftar mahasiswa setiap matakuliah yang diampu. Skenarionya dapat dilihat pada tabel 5.

Tabel 5 Skenario Use Case Melihat Daftar Mahasiswa

\begin{tabular}{|c|c|}
\hline Use case name & Melihat daftar mahasiswa \\
\hline Participating actor & User \\
\hline Flow of events & $\begin{array}{l}\text { 1. Aktor memilih mata kuliah di } \\
\text { halaman mata kuliah. } \\
\text { 2. Sistem menampilkan list daftar } \\
\text { mahasiswa berdasarkan mata } \\
\text { kuliah yang di pilih. }\end{array}$ \\
\hline Entry condition & User memilih mata kuliah \\
\hline Exit conditions & Sistem menampilkan list data mahasiswa \\
\hline Quality requirements & $\begin{array}{l}\text { Aplikasi akan menampilkan data yang } \\
\text { baru diisi }\end{array}$ \\
\hline
\end{tabular}

3. Skenario use case meng-input data presensi

Skenario ini merupakan kegiatan yang dilakukan oleh user untuk melakukan presensi terhadap kehadiran mahasiswa dengan NFC. Skenarionya dapat dilihat pada tabel 6 . 
Seminar Nasional Instrumentasi, Kontrol dan Otomasi (SNIKO) 2015 Bandung, Indonesia, 10-11 Desember 2015

Tabel 6 Skenario Use Case meng-input data presensi

\begin{tabular}{|c|c|}
\hline Use case name & Meng-input data presensi \\
\hline Participating actor & User \\
\hline Flow of events & $\begin{array}{l}\text { 1. Aktor memilih nama } \\
\text { mahasiswa di halaman daftar } \\
\text { mahasiswa } \\
\text { 2. Sistem menampilkan } \\
\text { halaman presensi } \\
\text { 3. Aktor meng-klik tombol } \\
\text { "Touch" untuk men-scan ID } \\
\text { card mahasiswa } \\
\text { 4. Aktor men-touch ID-card } \\
\quad \text { dengan perangkat } \\
\quad \text { mobile NFC } \\
\text { Sistem akan menampilkan } \\
\text { update status kehadiran di } \\
\text { halaman presensi }\end{array}$ \\
\hline Entry condition & $\begin{array}{l}\text { User memilih halaman daftar } \\
\text { matakuliah }\end{array}$ \\
\hline Exit conditions & $\begin{array}{l}\text { Sistem menampilkan perubahan } \\
\text { status presensi }\end{array}$ \\
\hline
\end{tabular}

\section{Implementasi dan Pengujian Sistem}

\subsection{Implementasi Sistem}

Implementasi sistem dari aplikasi ini terdiri dari implementasi antar muka, perangkat keras dan perangkat lunak. MySQL digunakan sebagai database pada sistem presensi ini. Antar muka aplikasi dan pemograman aplikasi dibangun menggunakan Basic4Android dan PHP.

\subsubsection{Implementasi Antarmuka Aplikasi}

Implementasi antarmuka aplikasi merupakan penerapan dari perancangan antarmuka yang telah dilakukan sebelumnya. Tampilan aplikasi di bangun dengan menggunakan fitur designer dari Basic4Android. Dalam implementasi antar muka ini akan disajikan beberapa antar muka aplikasi yang telah dibangun.

\section{Splashscreen}

Splashscreen merupakan halaman pertama yang akan tampil ketika aplikasi dijalankan. Halaman ini berisi tentang informasi singkat terkait aplikasi. Hasil implementasi dari halaman implementasi dapat dilihat pada gambar 9.

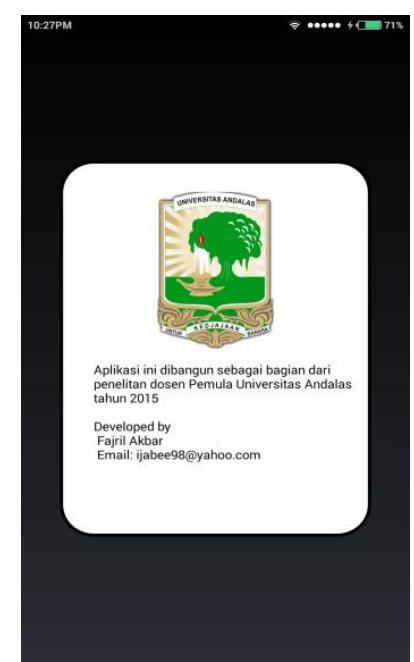

Gambar 9 antar muka splashscreen

\section{Antarmuka Login}

Halaman ini muncul setelah splashscreen. Halaman ini menampilkan form login user dan tombol Login. User yang berhasil divalidasi oleh sistem akan melihat popup "Welcome" dan sebaliknya, user yang tidak valid akan menerima popup error yang terjadi. Gambar 10 melihatkan hasil rancangan halaman login.
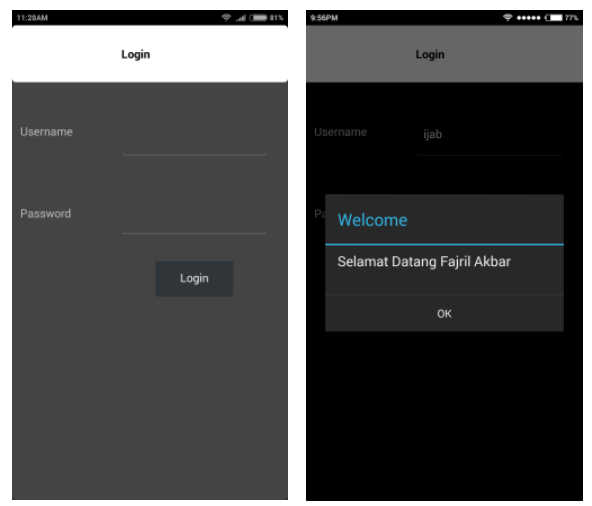

Gambar 10 Antar muka login

\section{Antarmuka daftar mahasiswa}

Halaman ini akan menampilkan daftar mahasiswa berdasarkan matakuliah yang dipilih sebelumnya. Pada bagian header juga ditampilkan nama mata kuliah yang terpilih. Tampilan dari halaman daftar mahasiswa dapat dilihat di gambar 11. 


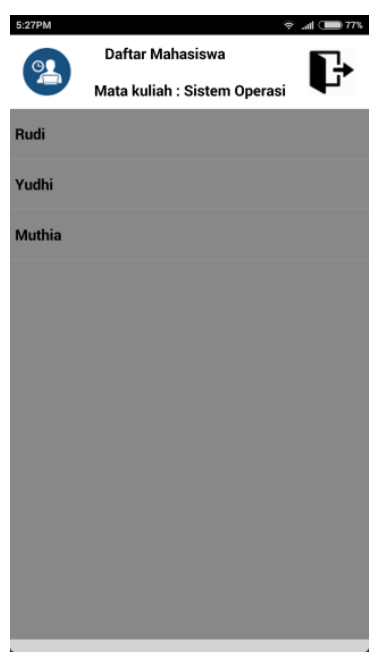

Gambar 11 antar muka daftar mahasiswa

4. Antar muka presensi

Antar muka ini menampilkan halaman interaksi antara sistem dengan perangkat NFC dan kartu RFID mahasiswa. Pada bagian header menampilkan data mahasiswa dan matakuliah sedangkan bagian footer menyajikan status presensi dan waktu. Hasil dari halaman presensi ini dapat dilihat pada gambar 12 .

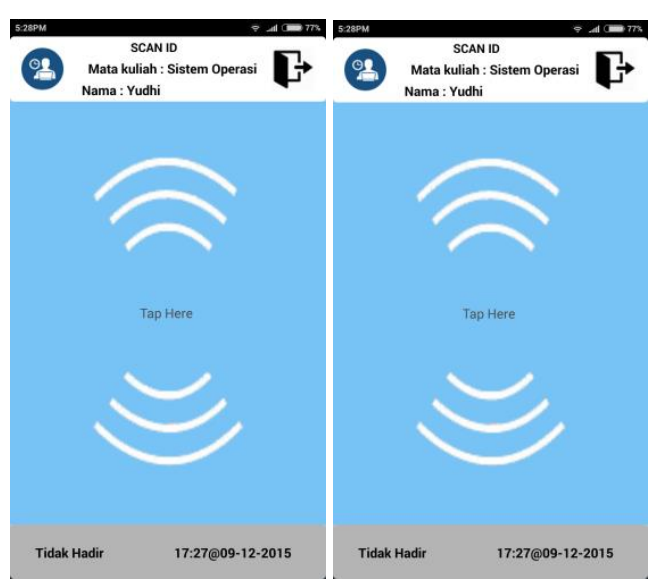

Gambar 12 antar muka presensi

\subsubsection{Implementasi Perangkat Keras:}

Implementasi sistem tediri dari infrastruktur perangkat keras dan perangkat lunak. Semua perangkat keras yang digunakan dalam penelitian ini terhubung menggunakan protocol komunikasi TCP/IP. Arsitektur there-tier client server diterapkan dalam sistem ini untuk memisahkan antara logika aplikasi dan manajemen data. Spesifikasi perangkat keras yang digunakan dalam sistem ini adalah

1. Web dan Database server

- $\quad$ Mini PC Raspberry pi 2

- $\quad$ Storage 16 GByte

2. Client Terminal berupa Smartphone Mi 3 dengan NFC terintegrasi

3. Wire and wireless Network Switch

Arsitektur dari semua perangkat keras dapat dilihat pada gambar 13 .

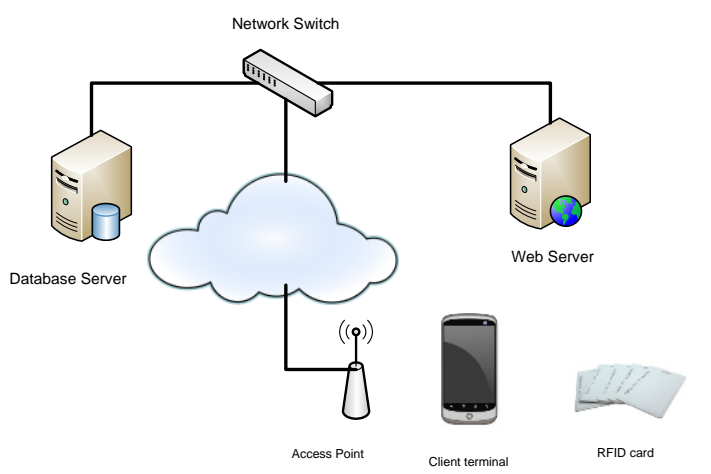

Gambar 13 arsitektur perangkat keras

\subsubsection{Implementasi Perangkat Lunak}

Pada penelitian ini digunakan beberapa perangkat lunak dalam pembangunan aplikasi dan implementasinya. Dalam tahap pembangunan aplikasi Android digunakan Basic4 Android dari Anywhere Software. Sedangkan dalam tahapan implementasi, spesifikasi perangkat lunak yang digunakan adalah sebagai berikut :

\section{Server side :}

- Sistem operasi menggunakan Raspbian OS

- Database server menggunakan MySQL

- Web server menggunakan Apache yang telah didukung dengan PHP

2. Client side

- Perangkat mobile dengan sistem operasi Android dengan Android SDK minimal versi 10.

\subsubsection{Implementasi pemograman pada perangkat Android}

Program aplikasi dibangun dengan menggunakan Basic4Android. Program yang 
dibangun hanya untuk platform Android. Hasil dari beberapa implmentasi program yang dibuat akan di lihatkan dalam bentuk potongan-potongan script program.

1. User dapat login ke sistem.

Potongan program ini berfungsi untuk proses validasi user dengan sistem. Jika user mengentrykan data username dan password yang valid, maka sistem akan menampilkan popup "Selamat Datang nama user". Jika data tidak valid akan menampilkan notifikasi kesalahan user. Gambar 14 merupakan potongan script untuk proses login user.

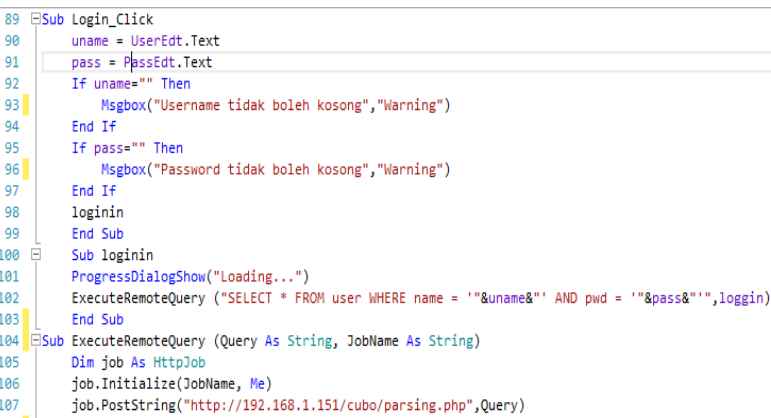

Gambar 14 potongan script proses login

2. User dapat melihat daftar mata kuliah

Pada potongan program ini, sistem dapat menampilkan semua daftar matakuliah yang di kelola oleh user. Sistem akan menampilkan hasil query mata kuliah ke database server dalam bentuk urutan (list). Gambar 15 merupakan potongan program untuk menampilkan daftar mata kuliah

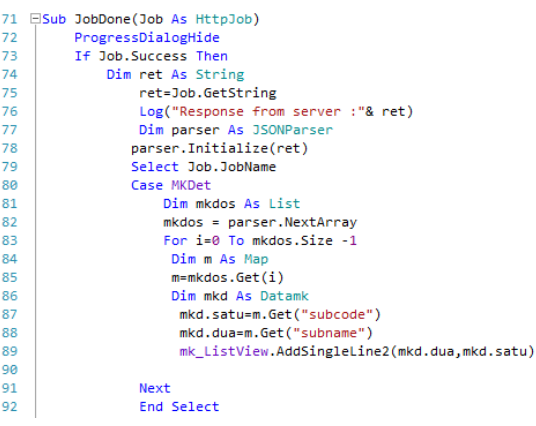

Gambar 15 script menampilkan daftar mata kuliah

3. User dapat melakukan presensi. Program ini berfungsi untuk mengaktifkan perangkat NFC dan menbaca data ID dari kartu RFID yang di-tag. ID yang terbaca akan dibandingkan dengan ID yang ada di sistem dan mengubah status ID tersebut di server database sistem. Gambar 16 memperlihatkan potongan program mengaktifkan perangkat NFC.

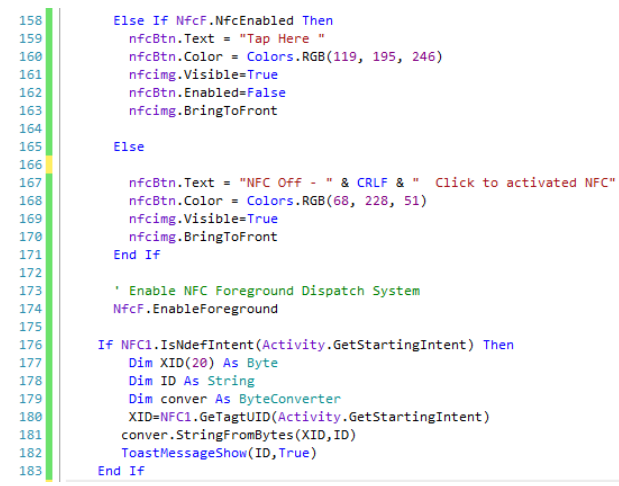

Gambar 16 script mengaktifkan perangkat NFC

\subsection{Pengujian Aplikasi}

Pengujian sistem dilakukan dengan Black Box testing. Pada black box testing, pengujian aplikasi dilakukan oleh tester berdasarkan kebutuhan fungsional perangkat lunak. Pengujian ini dilakukan berdasarkan 5 kebutuhan fungsional aplikasi yang telah dirancang sebelumnya.

Pada pengujian kebutuhan fungsional user melakukan login dilakukan tester dengan menggunakan username dan password yang valid maupun tidak valid.Pengujian tersebut dapat dilihat pada tabel tabel 8. Gambar 17 merupakan hasil query SQL pada database dan gambar 18 menunjukkan screenshot hasil pengujian.

Tabel 8 Pengujian Login user

\begin{tabular}{|l|l|}
\hline Aksi & $\begin{array}{l}\text { User memasukkan username “meza” } \\
\text { dan password “12345" dan “12345z" }\end{array}$ \\
\hline Ekpektasi & $\begin{array}{l}\text { Sistem akan menvalidasi data yang } \\
\text { dimasukkan dan merespon dengan } \\
\text { memberikan notifikasi }\end{array}$ \\
\hline Hasil & Terpenuhi \\
\hline
\end{tabular}




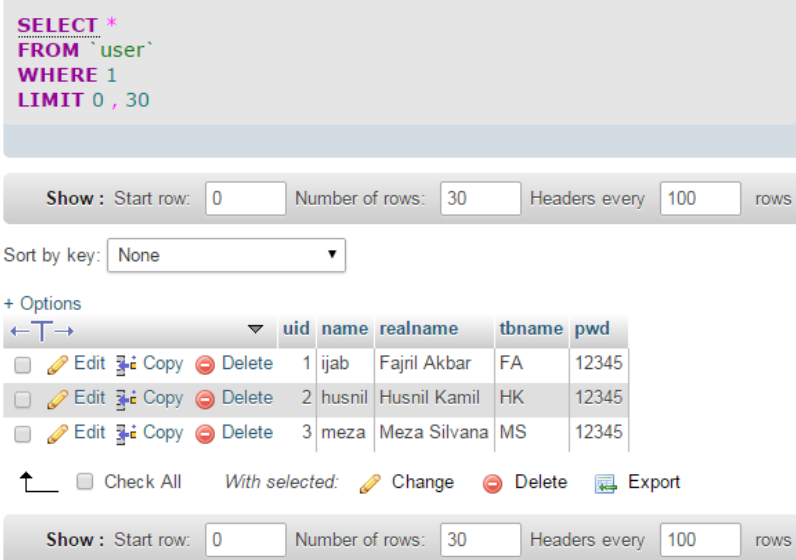

Gambar 16 query SQL data user pada database
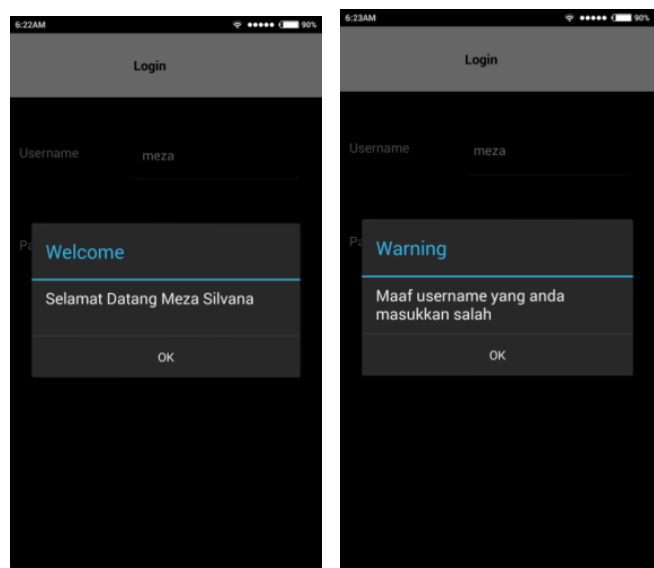

Gambar 16 hasil pengujian login

Pada pengujian kebutuhan fungsional user melihat daftar mahasiswa per mata kuliah dilakukan tester dengan memilih mata kuliah yang ditampilkan sistem.Pengujian tersebut dapat dilihat pada tabel tabel 9. Gambar 19 merupakan hasil query SQL pada database. Subcode "1" merupakan ID matakuliah dari egovernment. Gambar 20 menunjukkan tampilan output dari sistem.

\section{Tabel 8 Pengujian Login user}

\begin{tabular}{|l|l|}
\hline Aksi & $\begin{array}{l}\text { User login dengan username “ijab” dan } \\
\text { password “12345" dan kemudian } \\
\text { memilih mata kuliah e-government }\end{array}$ \\
\hline Ekpektasi & $\begin{array}{l}\text { Sistem akan menampilkan daftar } \\
\text { mahasiswa mata kuliah e-government }\end{array}$ \\
\hline Hasil & Terpenuhi \\
\hline
\end{tabular}

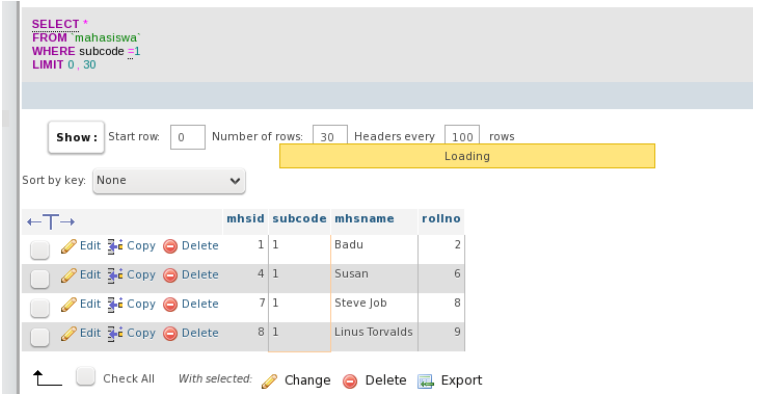

Gambar 19 query SQL data user pada database

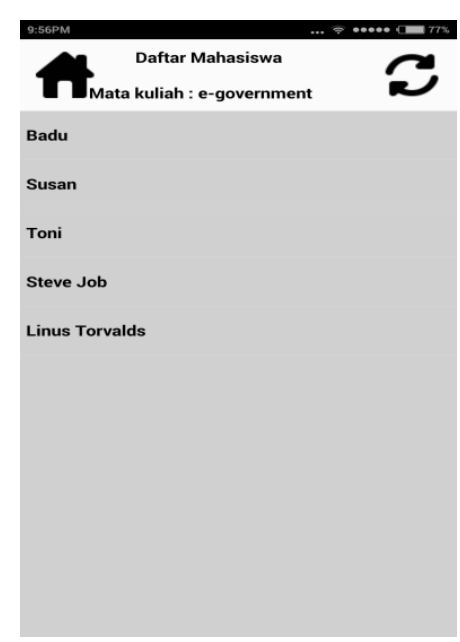

Gambar 20 hasil pengujian daftar mahasiswa mata kuliah e-government

\section{Kesimpulan}

1. Aplikasi mobile presensi dengan perangkat mobile NFC dan kartu RFID telah dibangun. Pada tahap perancangan telah dilakukan analisis terhadap kebutuhan aplikasi, dan kemudian telah di rumuskan 5 kebutuhan fungsional aplikasi dan 4 kebutuhan nonfungsional. Analisa kebutuhan juga dirancang dalam use-case diagram, context diagram maupun data-flow level 1 diagram. Pada tahap perancangan juga telah ditentukan desain antar muka, arsitektur sistem dan perancangan proses.

2. Pada tahap implementasi telah di bangun antar muka dan pemograman perangkat lunak dengan menggunakan Basic4Android.

3. Pengujian yang dilakukan menggunakan black box testing terhadap 4 kebutuhan fungsional aplikasi. 


\section{Ucapan Terima Kasih}

Penelitian ini didanai oleh Universitas Andalas melalui Program Penelitan Dosen Pemula tahun 2015, No Kontrak : 13/UN.16/PL/DM/2015.

\section{Daftar Pustaka}

[1] NFCWorld. About NFC. url: http://www.nfcworld.com/en/about/01.html. 2014. Diakses 19 Maret 2015

[2] IDC, Smartphone OS Market Share, 2015 Q2. http://www.idc.com/prodserv/smartphon e-os-market-share.jsp. 2015. Diakses 19 September 2015

[3] Handojo, A., Andjarwirawan, J, dan WONODIHARDJO, J. (2013). Aplikasi Presensi Kelas Kuliah Dengan Near Field Communication (NFC) Pada Android (Doctoral dissertation, Petra Christian University).

[4] Chien-wen Shen, Yen-Chun Jim Wu, Tsungche Lee, Developing a NFC-equipped smart classroom: Effects on attitudes toward computer science, Computers in Human Behavior, Volume 30, January 2014, Pages 731-738.

[5] Marcos J. López Fernández, Jorge Guzón Fernández, Sergio Ríos Aguilar, Blanca Salazar Selvi, Rubén González Crespo, Control of attendance applied in higher education through mobile NFC technologies, expert Systems with Applications, Volume 40, Issue 11, 1 September 2013, Pages 4478-4489

[6] Andreas Prinz, Philipp Menschner, Jan Marco Leimeister, Electronic data capture in healthcare-NFC as easy way for selfreported health status information, Health Policy and Technology, Volume 1, Issue 3, September 2012, Pages 137-144

[7] Abdulhadi Alqarni, Maali Alabdulhafith, Srinivas Sampalli, A Proposed RFID Authentication Protocol based on Two Stages of Authentication, Procedia Computer Science, Volume 37, 2014, Pages 503-510.

[8] Coskun V,Ozdenizci B, Ok K. A Survey on Near Field Communication (NFC) Technology. Wireless Personal ommunications, 2013,71(3):2259-2294.

[9] Lahtela A, Hassinen M, Jylha V. RFID and NFC in healthcare: Safety of hospitals medication care. Pervasive Computing Technologies for Healthcare, 2008. PervasiveHealth 2008. Second International Conference on. 2008. p.241244

[10] NFCForum. About the Forum, url: http://www.nfc-forum.org/aboutus/. 2014. Diakses 19 Maret 2014

[11] NFCWorld. About NFC. url: http://www.nfcworld.com/en/about/01.html. 2014. Diakses 19 Maret 2014 